
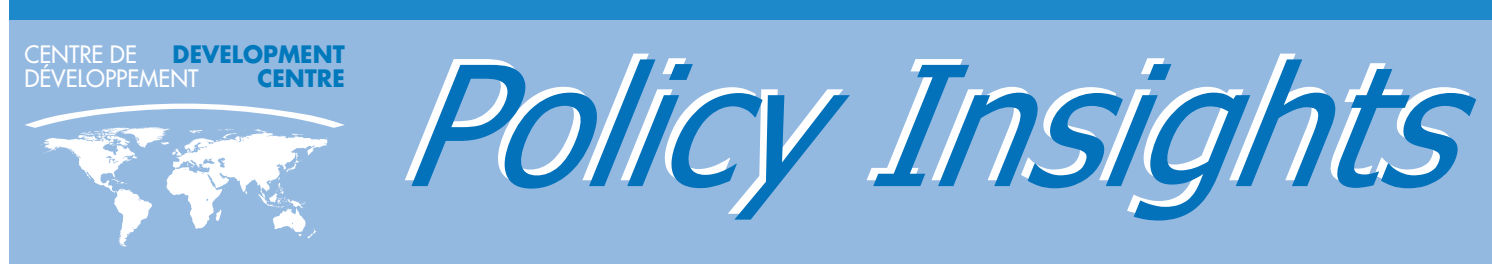

\title{
Should ASEAN Countries Embrace Carbon Labelling as a Means to Reduce Emissions?
}

by Ana Santillana

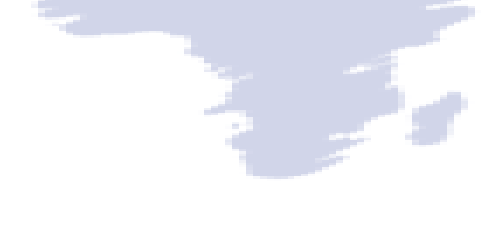

- ASEAN countries should play a more active role in the international standard-setting process for carbon labelling.

- Fragmented, bottom-up approaches to carbon labelling may lead to a proliferation of different labelling schemes, acting as a constraint to ASEAN exports.

- Carbon labelling should be part of ASEAN countries' environmental sustainability plans.

Carbon labelling is a supply chain management instrument that specifies greenhouse gas (GHG) emissions through a product's life-cycle assessment (LCA) from procurement of inputs, manufacturing, transport and distribution to final consumption and disposal of waste. It is increasingly applied as a tool for businesses and consumers to contribute to a reduction in GHG emissions. It is also considered as a policy lever for governments to use in order to navigate towards a low-carbon economy. ASEAN countries should embrace carbon labelling as part of their green growth policy but need to better understand a number of challenges involved before it becomes an effective policy tool.

The active participation of ASEAN countries in international standard-setting would be desirable

Carbon-labelling programmes are proliferating in developed countries. The focus and methodology used to calculate the carbon footprint of products - an estimation of the amount of GHG emissions through a product's LCA in tonnes of carbon dioxide equivalent (tCO2e) - differ considerably across organisations, businesses and governments in Europe, North America and Asia. From an environmental perspective, stakeholders could start reducing their GHG emissions more rapidly by using multiple voluntary standards. However, it would be desirable to develop internationally accepted standards. Various studies confirm that the use of different methodologies for calculating the carbon footprint of products leads to different outcomes. Moreover, the multiplicity of carbon labels diminishes their effectiveness in influencing consumers' behaviour. Consequently, the Carbon Trust, the International Organisation for Standardisation (ISO) and the World Resources Institute (WRI) are working together to create a worldwide accepted standard for determining embodied carbon emissions. It is crucial for ASEAN countries to co-operate and participate in the development of such a standard-setting process, because ASEAN countries have emerged as key participants in global supply chains since the mid-1990s. To date, however, the co-operation of carbon-labelling schemes both among ASEAN countries and with their business partners remains at an early stage.

\section{Labelling schemes could restrict developing countries' market access in a carbon- constrained economy}

Labelling schemes can be potentially detrimental to exports from developing countries if captured by protectionist interests in importing countries. Leastdeveloped countries (LDCs) are especially at risk because of the capacity constraint. In the Asia-Pacific region, for instance, carbon footprint activities have been implemented primarily in developed countries, with the exception of Thailand (see Table). ASEAN LDCs, Cambodia, Lao PDR and Myanmar, are still very much concerned about poverty reduction and economic development. 
Carbon-labelling schemes in the Asia-Pacific region

\begin{tabular}{|c|c|c|}
\hline Asia-Pacific region & Carbon label & Year of implementation \\
\hline Japan & Carbon Footprint of Products & 2009 \\
\hline Thailand & Carbon Reduction Label; and Carbon Footprint Label & 2009 \\
\hline Korea & Carbon Footprint Certification Label & 2009 \\
& Low Carbon Product Certificate & 2011 \\
\hline Australia & Carbon Reduction Label & 2010 \\
\hline New Zealand & Carbon Reduction Label & 2010 \\
\hline Chinese Taipei & Carbon Reduction Label & 2010 \\
\hline China & Under development & \\
\hline Malaysia & Under development & \\
\hline Singapore & Under development & \\
\hline
\end{tabular}

Source: Adapted from SHI, 2010.

Methodology bias against developing nations, such as the use of "food miles" (see Box), must be avoided. Other biases include the Publically Available Specification (PAS) 2050's consideration of emissions of recent land use change and the lack of appropriate weight given to labour-intensive techniques and other carbon-efficient methods of production. Countries using carbon labelling should be transparent regarding their methodologies and sensitive to the lack of technical and financial resources of LDCs to employ such methodologies. In this regard, effective assistance to capacity building in LDCs should be given a priority so that their exports are not unfairly affected. Environmental consciousness should not be at odds with the important role that international trade can play in promoting economic and social development and reducing poverty in ASEAN countries.

\section{"Food miles" can have a negative effect on developing countries' exports}

The concept of "food miles" - the measurement of embodied carbon in a traded good as a result of its transport - has gained popularity in the European Union and the United States. Yet a number of LCA studies have shown that locally produced goods do not necessarily guarantee a reduction in total GHG emissions. GHG emissions from transport may be more than compensated by carbon efficient processes of production in developing countries. This labelling scheme may be seen as a case of "green protectionism" since it discriminates against exporting nations, particularly developing countries whose exports depend on longdistance transportation. Labelling schemes which take into account a product's full life cycle are not as likely to discriminate against developing countries as "food miles".

\section{Carbon labelling should be part of ASEAN countries' climate change mitigation actions}

Though still in their infancy, carbon-labelling schemes have been evolving rapidly in the developed world. It cannot be denied that this policy instrument can influence the behaviour of green-conscious consumers, thereby forcing change within the supply chain. There is still time for ASEAN countries to have a strong voice in this global attempt to reduce GHG emissions. By participating in the process of international standards for carbon-labelling programmes and by developing such programmes as part of green growth policy, ASEAN countries can gain positive spillovers arising from this international endeavour to benefit the environment.

\section{Further reading}

OECD (2005), "Effects of Eco-labelling Schemes: Compilation of Recent Studies", Joint Working Party on Trade and Environment, OECD, Paris.

BRENTON, P., G. EDWARDS-JONES and M.F. JENSEN (2009), "Carbon Labelling and Low-income Country Exports: A Review of the Development Issues", Development Policy Review, 27(3): 243-267.

SHI, X. (2010), "Carbon Footprint Labeling Activities in the East Asia Summit Region: Spillover Effects to Less Developed Countries", ERIA Discussion Paper Series, Economic Research Institute for ASEAN and East Asia, Jakarta, July 2010.
Readers are encouraged to quote or reproduce material from OECD Development Centre Policy Insights for their own publications. In return, the Development Centre requests due acknowledgement and a copy of the publication. Full text of Policy Insights and more information on the Centre and its work are available on its web site: www.oecd.org/dev

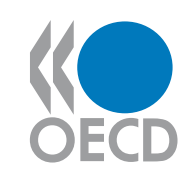

OECD Development Centre 2 , rue André-Pascal, 75775 Paris Cedex 16, France Tel.: +33-(0)1 45.24.82.00 Fax: +33-(0)144306149 E-mail: dev.contact@oecd.org 